\title{
Poly(A) Polymerase Gamma
}

National Cancer Institute

\section{Source}

National Cancer Institute. Poly(A) Polymerase Gamma. NCI Thesaurus. Code C38951.

Poly(A) polymerase gamma (736 aa, $\sim 83 \mathrm{kDa}$ ) is encoded by the human PAPOLG gene.

This protein plays a role in RNA polyadenylation. 